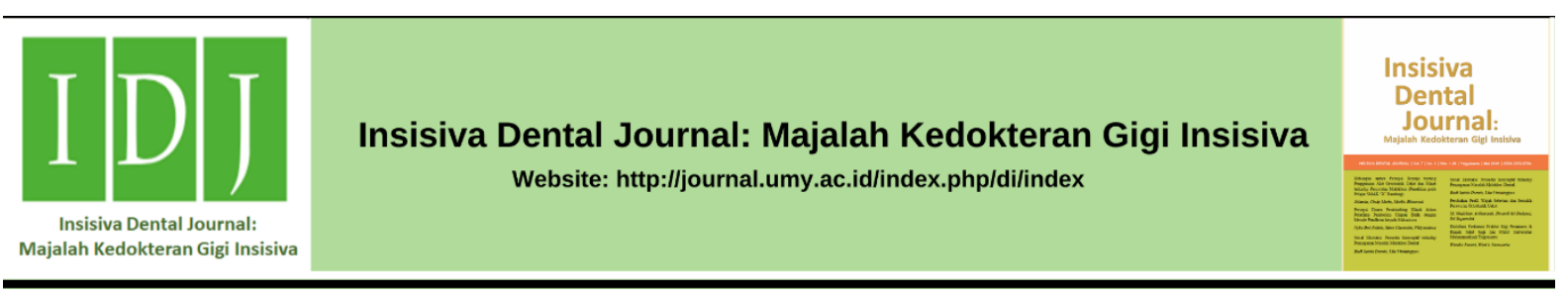

Case Report

\title{
Odontektomi Impaksi Kaninus Maksila Bilateral Palatal dengan Anestesi Lokal
}

Odontectomy of Palatal Bilateral Maxillary Canine Impaction under Local Anesthesia

\section{Edwyn Saleh*}

Departemen Bedah Mulut, Program Studi Kedokteran Gigi, Fakultas Kedokteran dan Ilmu Kesehatan, Universitas Muhammadiyah Yogyakarta, Jalan Brawijaya, Tamantirto, Kasihan, Bantul, Indonesia.

Received date: September $28^{\text {th }}, 2020$; reviewed date: October $10^{\text {th }}, 2020$ revised date: October $17^{\text {th }}, 2020$; accepted date: October $30^{\text {th }}$, 2020 DOI : 10.18196/di.9220

\begin{abstract}
Abstrak
Impaksi gigi kaninus maksila yang terletak di sebelah palatal umumnya tidak memberikan gejala sakit seperti gigi impaksi yang lain. Pengambilan gigi kaninus maksila yang mengalami impaksi pada dasarnya mengikuti prinsip pengambilan gigi impaksi secara umum, dengan penekanan pada pemeriksaan letak posisi gigi pada rontgen foto. Tujuan dari operasi ini adalah untuk mengeluarkan gigi kaninus yang impaksi, kondisi tersebut menjadi faktor predisposisi terjadinya kista dentigerous. Anak perempuan usia 15 tahun mengeluhkan adanya benjolan pada maksila bilateral sebelah palatal. Benjolan tersebut dirasakan muncul sejak satu tahun yang lalu tanpa disertai rasa sakit. Pemeriksaan radiografis menunjukkan impaksi gigi kaninus dan tumbuh miring ke arah mesial. Odontektomi dilakukan secara intraoral dengan anastesi lokal. Tindakan odontektomi berhasil dilakukan tanpa komplikasi. Pengambilan gigi impaksi bilateral kanan dan kiri sangat jarang dilakukan, namun pada laporan ini dilakukan secara bersamaan karena posisi kedua gigi kaninus dalam satu regio anterior yang berdekatan dan mengarah ke mesial atau median line. Tindakan ini dilakukan untuk mempercepat penanganan pada kasus impaksi untuk menghindari trauma operasi pada pasien anak.
\end{abstract}

Kata Kunci: Anestesi Lokal; Impaksi Kaninus Bilateral; Odontektomi

\begin{abstract}
Palatal impacted maxillary canines are generally not as painful as other impacted teeth. The extraction of maxillary canines that improves impaction basically also requires the principles of taking the dental implications in general, with a careful compilation of $x$-rays examination for the impacted teeth's position, accessible at the palatal or labial. This surgery aimed to remove the teeth that have not yet completely erupted and eliminate a dentigerous cyst's predisposing factors. A 15-year-old female patient complained of a lump in the oral cavity roof on the left and right sides but without pain. Radiographic examination showed that the maxillary canine teeth did not erupt in place and were tilted toward the mesial. The odontectomy surgery was performed intraorally with local anesthetics. This method's choice was because the teeth's position that had been prominent on the palatal side was clearly visible, and for the trauma, the patient would perform the surgery with general anesthesia. The right and left maxillary canines were removed intraorally without coordination. Extractions of right and left bilateral impacted teeth are extremely rare, but this report was performed in the position of the two canines in the anterior region, where both teeth were directed toward the mesial or median line. This action was done to improve the case management of teeth that did not grow in place and avoid surgical trauma in patients, given the patient's relative age.
\end{abstract}

Keywords: Local Anesthesia; Bilateral Canine Impaction, Odontectomy

\footnotetext{
* Corresponding author, e-mail: edwynsaleh@gmail.com
} 


\section{PENDAHULUAN}

Odontektomi adalah tindakan pengambilan atau ekstraksi gigi impaksi yang hanya muncul sebagian atau sepenuhnya tidak muncul atau pada gigi yang tinggal sisa akar sehingga tidak bisa dilakukan pencabutan dengan teknik biasa dengan metode tertutup (close method) sehingga harus melalui pembedahan dengan metode terbuka (open method). ${ }^{1}$ Gigi kaninus rahang atas merupakan impaksi gigi yang sering muncul dan ditemukan dalam keadaan terpendam dalam tulang maksila, dalam kasus demikian maka pengambilan gigi dilakukan dengan metode operasi pembedahan dengan cara mengambil gigi kaninus secara bersamaan atas pertimbangan posisi kedua kaninus yang mengarah ke median line. ${ }^{2}$

Kasus impaksi biasanya ditemukan saat pasien datang ke dokter gigi dengan keluhan pusing kepala yang belum diketahui penyebabnya. Terdapat beberapa faktor umum yang menjadi penyebab gigi impaksi yaitu trauma pada rongga mulut saat tumbuh kembang, infeksi gigi desidui maupun jaringan sekitar erupsi gigi dan gangguan sistemik perkembangan erupsi gigi serta kondisi tulang rahang yang abnormal. $^{2}$ Kasus impaksi gigi kaninus rahang dapat dengan mudah dideteksi melalui radiografi dan ditegakkan diagnosa, namun pada saat tindakan pembedahan biasanya akan lebih sulit daripada yang diperkirakan dari gambaran radiografis. Pada saat tindakan operatif odontektomi ada beberapa komplikasi yang sering muncul saat dilakukan operasi yaitu fraktur pada akar gigi, trauma jaringan lunak dan jaringan tulang area operasi serta dimungkinkan terjadi rusaknya dinding sinus maksilaris akibat trauma pembedahan. ${ }^{3}$

Terdapat dua faktor etiologi gigi impaksi yaitu faktor primer dan sekunder. Etiologi pada faktor primer dijelaskan akan berkaitan dengan riwayat benturan pada gigi desidui, kondisi benih gigi yang mengalami perubahan posisi, kondisi kehilangan gigi desidui sebelum masanya, dan posisi gigi kaninus pada kasus celah langit. Sedangkan etiologi faktor sekunder meliputi adanya kelainan sistemik seperti pada gangguan endokrin, febrile diseases dan defisiensi vitamin D. ${ }^{4}$

Teknik operasi pengambilan gigi impaksi terdapat dua pendekatan tindakan melalui akses luar rongga mulut dan dalam rongga mulut. Pendekatan tindakan operasi akses luar rongga mulut biasa yang dilakukan dengan insisi pada submandibular atau preaurikular. Sedangkan akses melalui rongga mulut disarankan menjadi pilihan utama karena pendekatan metode ini tidak menimbulkan jejas luka pada area wajah pasien, tetapi pada beberapa kasus gigi impaksi ektopik yang dekat dengan kondilus maka akses ke subcondylar atau wilayah condylar mungkin sulit dicapai dari dalam rongga mulut melainkan akan lebih mudah dicapai melalui akses luar rongga mulut. ${ }^{5}$

Impaksi gigi kaninus rahang atas yang terletak disebelah palatal umumnya tidak memberikan gejala sakit seperti gigi impaksi yang lain, kecuali mengalami infeksi atau merasa terganggu dengan keberadaan gigi tersebut karena adanya tonjolan di daerah palatal. Proses pengambilan gigi kaninus impaksi pada rahang atas akan berdasar pada prinsipprinsip pengambilan gigi impaksi secara umum, dengan penekanan pada pemeriksaan secara cermat melalui rontgen foto berdasarkan posisi gigi tersebut, terletak di palatal atau di labial, yang dapat dilakukan dengan Metode Shift Sketch. ${ }^{5}$ Pada kasus ini, metode tersebut diabaikan, karena kedua gigi kaninus yang impaksi tersebut secara klinis sudah terlihat tumbuh di sebelah palatal, dan dengan deteksi secara palpasi sudah dapat dipastikan karena adanya benjolan gigi impaksi tersebut disebelah palatal.

\section{LAPORAN KASUS}

Pasien wanita 15 tahun mengeluhkan adanya benjolan pada langit- 
langit rongga mulut di sisi kiri dan kanan bagian depan tanpa ada keluhan sakit, pasien merasa sering pusing kepala yang tajam dan tanpa sebab yang pasti. Benjolan tersebut dirasakan muncul dalam satu tahun terakhir. Pasien merasakan ada benjolan di langit-langit ketika ujung lidah menjangkau daerah langit-langit bagian depan. Pemeriksaan ekstraoral menunjukkan wajah tampak simetris, tidak tampak benjolan secara ekstraoral di regio anterior rahang atas, sedangkan pemeriksaan intraoral terlihat benjolan pada mukosa palatal regio anterior sisi kanan dan kiri dibelakang gigi incisivus kedua kanan dan kiri (gambar B). Gambaran radiografis menunjukkan gigi 13 dan 23 tidak erupsi pada tempatnya dan tumbuh miring kearah mesial (gambar A). Assesment pada kasus ini adalah gigi 13 dan 23 impaksi mengarah ke mesial. Rencana perawatan pada kaus ini adalah odontektomi pendekatan akses intraoral dengan anestesi lokal, pemilihan metode pengambilan akses intraoral dengan lokal anastesi karena posisi gigi yang telah menonjol di sisi palatal secara visual tampak jelas dan juga untuk menghindari trauma pasien akan tindakan operasi dengan anestesi umum.

\section{Prosedur operasi}

Secara umum, prosedur odontectomy untuk pengambilan gigi impaksi terdiri dari beberapa langkah.

Pembuatan Flap ditujukan untuk memberikan akses yang memadai. Seperti diketahui, kesulitan utama dari pengambilan gigi impaksi adalah karena sulitnya akses menuju gigi tersebut. Envelope flap merupakan flap yang paling banyak digunakan, karena flap ini mudah ditutup dan lebih mudah mengalami penyembuhan dibandingkan dengan jenis flap yang lain. Tetapi bila dalam prosedur pembedahan diperlukan akses yang lebih besar yang mungkin akan menyebabkan robek pada envelope flap, dapat digunakan three-corner flap. ${ }^{5}$ Pertimbangan yang perlu mendapat perhatian selain faktor diatas dalam pembuatan flap adalah mempertimbangkan letak pembuluh darah dan syaraf, sehingga pembuatan flap tidak akan mengganggu keberadaan struktur yang vital; pembuatan flap harus lebih lebar dari bagian free margin flap tersebut, yang bertujuan menjamin suplai darah yang memadai pada flap; buat flap dengan lebar yang memadai sehingga akan memberi lapang pandang dan akses yang memadai untuk pelaksanaan prosedur pembedahan; menggunakan scalpel tajam dengan posisi tetap kontak dengan tulang pada saat melakukan insisi. Pemotongan yang berulang-ulang akan menyebabkan trauma yang tidak diharapkan pada periosteum dan mempersulit proses penyembuhan. ${ }^{2}$

Pengurangan tulang pada dasarnya dilakukan untuk membuat daerah yang dapat digunakan untuk mengaplikasikan elevator, membuka jalan untuk melakukan pemecahan pada gigi, dan menghilangkan hambatan bagi jalan pengeluaran gigi. Pengambilan tulang dapat dilakukan baik dengan menggunakan bur maupun dengan chisel 3, 6. Pengambilan tulang pertamatama dilakukan pada bagian oklusal dan dilanjutkan dengan bagian yang mengarah menuju garis servikal. Banyaknya tulang yang diambil adalah tergantung pada kedalaman impaksi, morfologi akar dan angulasi gigi. ${ }^{6}$

Pemecahan gigi dilakukan apabila jumlah tulang yang diambil telah memadai. Langkah ini bertujuan untuk membuka jalan keluar, memungkinkan akan bergerak sesuai dengan arah pengeluarannya masing-masing, untuk mencegah kerusakan saraf, dan untuk mempertahankan tulang. Pemecahan gigi ini dapat dilakukan dengan bur, dengan chisel atau dengan kombinasi keduanya. ${ }^{7}$ Pemecahan gigi ini sangat tergantung kepada angulasi gigi tersebut. ${ }^{5}$

Pengeluaran gigi dilakukan apabila gigi telah dipecah, selanjutnya dapat dilakukan pengeluaran gigi dari dalam soketnya dengan menggunakan elevator maupun cryer. Salah satu perbedaan mendasar dari pengeluaran gigi impaksi dibandingkan dengan pencabutan gigi dengan cara yang lain adalah pada prosedur 
ini tidak dilakukan luksasi. ${ }^{7}$ Melakukan elevasi pada odontectomy harus dilakukan secara hati-hati karena penggunaan kekuatan yang berlebihan pada tahap ini akan dapat menyebabkan fraktur pada tulang sekitar gigi tersebut. Bila pada saat ini pengeluaran gigi masih sulit dilakukan, maka tindakan untuk memeriksa kembali gigi tersebut dan penentuan penyebab retensi tersebut harus dilakukan. Selanjutnya langkah-langkah seperti pengambilan tulang yang lebih banyak atau pemotongan kembali bagian akar dapat dilakukan. ${ }^{8}$ Setelah gigi impaksi berhasil dikeluarkan dari tulang alveolar, perhatian selanjutnya diarahkan untuk melakukan debridement pada luka yaitu membersihkan luka dari semua serpihan tulang dan debris yang ada. Prosedur ini dapat dilakukan dengan irigasi pada luka dengan menggunakan salin yang steril. Prosedur ini juga dilakukan secara seksama pada bagian bawah jaringan flap, dan dapat dilakukan dengan menggunakan periapical curette. ${ }^{5}$

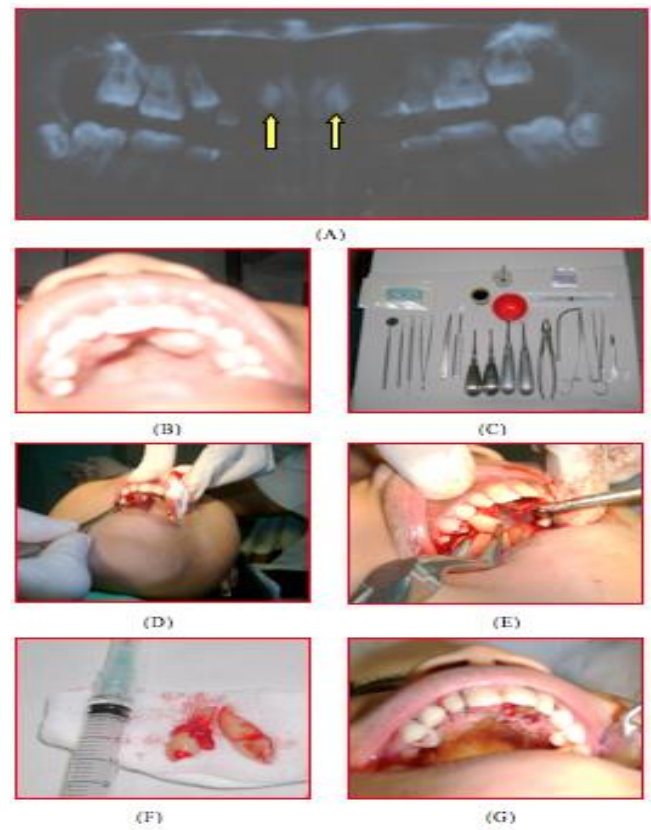

Gambar 1. Proses pengambilan gigi impaksi kaninus maksila bilateral. (A) Ortho Panoramic Graft (OPG) menunjukkan posisi gigi impaksi kaninus maksila bilateral (tanda panah). (B) Posisi secara klinis di palatal. (C) Peralatan Operasi. (D) Flap insisi palatal. (E) Ekstraksi gigi impaksi. (F) Gigi kaninus telah berhasil diekstraksi (G) Penutupan luka operasi
Penjahitan luka adalah salah satu aspek terpenting dari suatu operasi, dan seringkali memerlukan perhatian. Penutupan flap pada luka dilakukan dengan menempatkan kembali flap yang telah dibuka pada tempatnya semula dan dijahit untuk imobilisasi posisi margin pada tempat semula. Penjahitan hendaknya dilakukan dengan melibatkan keseluruhan ketebalan flap mukoperiosteal. ${ }^{7}$

\section{HASIL}

Kasus tindakan operasi pada pasien ini menunjukkan hasil pada hari pertama pasca tindakan operasi pasien sudah dapat beraktifitas normal biasa mobilisasi diri tidak terganggu. Keluhan-keluhan yang sering muncul pada pasca operasi odontektomi meliputi rasa pusing, mual dan nyeri hebat tidak dirasakan oleh pasien. Satu minggu pasca operasi dilakukan kontrol kedua yang menunjukkan pasien dengan kondisi umum baik tidak keluhan nyeri hebat, pemeriksaan objektif intraoral menunjukkan bekas luka bekas operasi kering tanpa pendarahan jahitan luka masih stabil, tidak tampak adanya inflamasi akut dan tanda infeksi, selanjutnya dilakukan pengambilan benang jahitan. Satu bulan pasca operasi pasien datang untuk kontrol ketiga menunjukkan tidak ada keluhan sakit dan pasien sudah merasa biasa saja pada rongga mulutnya, pemeriksaan obyektif tidak ada pembengkakan, tidak ditemukan indikasi terjadi parestesia, penyembuhan jaringan lunak palatal area operasi sudah sembuh dengan baik.

\section{PEMBAHASAN}

Gigi impaksi adalah gigi yang erupsi sebagian atau tidak erupsi sama sekali, melampaui waktu kronologis erupsi, dan tidak menunjukkan hubungan normal dengan gigi dan jaringan lainnya. Menurut Renton, gigi impaksi adalah gigi yang terletak di dalam tulang rahang, seluruhnya tertutup oleh jaringan lunak dan sebagian atau seluruhnya tertutup jaringan tulang. ${ }^{1,9}$ Pendekatan tindakan bedah pada kasus ini menjadi pilihan utama dikarenakan posisi 
gigi kaninus impaksi lebih di area palatal, sehingga prognosis baik. Pendekatan melalui traksi ortodontik pada gigi tersebut prognosis kurang baik. Tindakan pembedahan pada kasus ini dengan pertimbangan dari keluhan utama pasien adanya rasa pusing atau sakit kepala yang tanpa sebab secara berulang-ulang. Sakit kepala yang berasal dari regio intracranial dapat disebabkan karena (a) Adanya perubahan tekanan darah dapat menyebabkan tegang pada arteri intracranial, (b) Berbagai penyakit tulang seperti osteitis deformans, akromegali dan osteoporosis yang berakibat bisa terjadi kontraksi foramina cranial dan tekanan pada saraf, (c) Pada basis otak terjadi traksi dinding sinus venosus, a. meningea media dan cabang- cabang circulus Willis (d). Tekanan dan traksi karena tumor intrakranial, (e) Radang pada area duramater, sinus venosus dan arteri sensoris. Keluhan sakit kepala pada pasien ini kemungkinan timbul karena kondisi impaksi kedua gigi kaninus atas yang menstimulasi ujung-ujung saraf atau tekanan yang mengenai saraf (neuralgia) pada nervus alveolaris superior anterior serta medius. ${ }^{10,11}$

Nervus alveolaris superior membentuk Plexus yang mempunyai berhubungan erat dengan ujung akar dari gigi-geligi rahang atas, plexus terbentuk melalui distribusi tiga cabang saraf yang tumpang tindih. Incisivus mendapat persarafan dari rami anterior, kaninus dari rami anterior dan medius, premolar dari rami medius, serta molar atas dari rami medius dan rami posterior. Sensasi yang timbul dengan adanya stimulus pembentukan plexus tersebut akan terdistribusi pada ligamentum periodontal yang kemudian direspon sebagai sensasi tekanan dan rasa sakit. ${ }^{10}$

Tinjauan kasus dari ini dimana usia pasien 15 tahun termasuk kategori masa tumbuh kembang anak. Pada masa ini pertumbuhan dari sutura-sutura tulang kranial akan berakibat terjadi pergerakan tulang maksila ke anteroinferior (depan dan bawah), sehingga tengkorak akan bergeser ke posterosuperior (belakang dan atas). Pertumbuhan maksila pada processus alveolaris dan processus palatinus terjadi karena adanya oposisi dari tulang alveolar pada saat gigi-geligi rahang atas akan erupsi. Pada waktu maksila tumbuh ke bawah, terjadi aposisi dasar orbita, dasar hidung, dan permukaan palatum. ${ }^{11}$ Pada saat yang bersamaan akan diimbangi oleh adanya kontraksi otot-otot wajah (musculus orbicularis oris dan musculus buccinator). Otot-otot tersebut juga dapat mengimbangi tekanan otot-otot lingua pada permukaan dalam arcus dentalis. Bila keseimbangan terganggu, maka dapat terjadi perubahan posisi gigi. ${ }^{10,11}$ Faktor-faktor itulah yang kemungkinan dapat berpengaruh terhadap posisi gigi impaksi pada kaninus yang letaknya berada di dalam tulang maksila area palatal.

Pasca pencabutan gigi dengan metode pembedahan tentunya akan berimplikasi pada sebuah komplikasi yang menyertai, terdapat beberapa respon normal secara fisiologis pasca operasi, yaitu adanya perdarahan, bengkak area operasi karena proses inflamasi, kekakuan otot dan rasa nyeri saat membuka mulut. Adanya respon negatif tersebut tentunya akan muncul rasa tidak nyaman bagi pasien dalam jangka pendek biasanya akan berlangsung selama tiga sampai tujuh hari setelah pembedahan. ${ }^{3}$ Pada kasus ini komplikasi-komplikasi tersebut tidak muncul sampai pada kontrol kedua yaitu satu bulan pasca pembedahan, luka bekas operasi sudah tidak nampak sama sekali dan jaringan lunak sudah kembali sesuai anatomi lengkung maksila.

\section{KESIMPULAN}

Impaksi gigi 13 dan 23 dengan posisi di sebelah palatal dan masing-masing mengarah ke mesial terindikasi menjadi predisposisi timbulnya efek sakit kepala tanpa sebab secara berulang, oleh karenanya dilakukan tindakan pencabutan gigi 13 dan 23 secara odontektomi, metode pendekatan akses tindakan operasi 
odontektomi dari area palatum dengan anestesi lokal dengan mempertimbangkan usia pasien dan lokasi gigi impaksi. Tindakan odontektomi secara bersamaan pada kedua gigi impaksi ini dapat menghilangkan rasa sakit kepala pasien, terlihat dari kontrol pertama pada hari ketujuh pasca operasi dan kontrol kedua sebulan pasca operasi pasien tidak lagi mengeluhkan sakit kepala yang sama sebelum tindakan operasi.

\section{DAFTAR PUSTAKA}

1. Balaji SM. Textbook of Oral and Maxillofacial Surgery. 2nd ed. New Delhi: Elsevier; 2013.

2. Peterson LJ. Principles of Management of Impacted Teeth. In: Ellis E, Hupp JR, Tucker MR, editors. Contemporary Oral and Maxillofacial Surgery. St. Louis: Mosby; 2014.

3. Ruslin M, \& Poedjiastoeti W. Buku Ajar Bedah Mulut dan Maksilofasial. Jakarta: EGC; 2019.

4. Slootweg, Pieter J. Dental Pathology: A Practical Introduction. 2nd ed. Berlin: Springer-Verlag; 2013.

5. Hsu YC, Kao CT, Chou CC, Tai WK, Yang PY. Diagnosis and Management of Impacted Maxillary Canines. Taiwanese Journal of Orthodontics. 2020;31(1):1-11.
6. Becker A, \& Chaushu S. Surgical Treatment of Impacted Canines: What the Orthodontist Would Like the Surgeon to Know. Oral Maxillofac Surg Clin North Am. 2015;27(3):449458.

7. Bedoya MM, \& Park JH. A review of the diagnosis and management of impacted maxillary canines. J Am Dent Assoc. 2009;140(12):1485-1493.

8. Sajnani AK, \& King NM. Diagnosis and localization of impacted maxillary canines: comparison of methods. J Investig Clin Dent. 2013;4(4):252-256.

9. Renton T. Surgical Management of Third Molars. In: Andersson L, Kahnberg KE, Pogrel MA, editors. Oral and Maxillofacial Surgery. West Sussex: Wiley-Blackwell; 2010.

10. Biswas N, Biswas SH, Shahi AK. Maxillary Impacted Canine: Diagnosis and Contemporary Ortho Surgical Management Guidelines. Int J Sci Stud. 2016;3(10):166-170.

11. Lai CS, Suter VG, Katsaros C, Bornstein MM. Localization of impacted maxillary canines and root resorption of neighbouring teeth: a study assessing the diagnostic value of panoramic radiographs in two groups of observers. Eur J Orthod. 2014;36(4):450-456. 